MIRJANA VOJVODA

Institute of Archaeology,

Belgrade, Serbia

mirjana.vojvoda@gmail.com
904:737.1.032.044(37)"0071"

COBISS.SR-ID 228046604

Original research article

Received: November $9^{\text {th }} 2015$

Accepted: June $20^{\text {th }} 2016$

\title{
SIGNIS RECEPTIS AS A REVERSE MOTIVE ON ROMAN IMPERIAL COINS
}

\begin{abstract}
Different signa militaria played an important role in legionaries' religious life, possessing a deep symbolic meaning. The highest honours were paid to the legionary eagle which, together with other insignia, was kept in a special sanctuary within a military camp. During battle, legionaries followed their insignia and died for them, since their loss would represent the biggest disgrace and meant the dismissal of a legion. Romans rarely lost their aquilae, and even if they did, they would attempt to retrieve them for decades. Some of these events were depicted on coins, with the inscription SIGNIS RECEPTIS. They are encountered on the coins of Augustus, Caligula and Vespasian.
\end{abstract}

\section{KEYWORDS: ROMAN IMPERIAL COINS, REVERSE IMAGES, SIGNA MILITARIA, SIGNIS RECEPTIS.}

The religion of the Roman military was special and complex and, during the Principate, it was based on two components ${ }^{1}$. First of all, there was the official cult of the emperor and the cult of state deities, but there was also a private, soldier's cult (local deities from a soldier's place of birth or from places where he was previously stationed, as well as local deities from the area of the actual military camp), practiced by groups or individuals seeking the protection of deities (Stoll 2007, 451). A special place, with deep symbolic meaning for soldiers, was taken by different signa militaria, which they followed into battle, died for, the loss thereof representing the greatest disgrace and usually meant the dismissal of a legion. Military insignia played an exceptional role in

1 The article results from the project: Viminacium, Roman city and military camp - research of material and non- material culture of inhabitants by using the modern technologies of remote detection, geophysics, GIS, digitalization and $3 D$ visualization (no 47018), funded by The Ministry of Education, Science and Technological Development of the Republic of Serbia. soldiers' everyday and religious life. They were worshipped as spiritual divinities, as they were deeply incorporated into the Roman military ideology and symbolism. They represented signs of the bravery and morals of each military unit and a stronghold of its pride and were kept in a special sanctuary within each military camp. ${ }^{2}$ However,

2 There is a difference between signa, vexilla and aquilae (RE II.A.2: 2325-2327 (signa militaria), RE VIII.A.2: 2446-2454 (vexillum), RE II: 317-318 (aquila)). Each maniple and cohort possessed its own signa - a spear with a crossed piece of wood on top, while on the spear there were circular medallions and wreaths, often with a hand on the very top. During Republican times, on medallions, there were images of Mars or Minerva, while from the beginning of the Principate, there was an image of an actual or deified emperor (imagines). Vexilla belong to the oldest type of insignia, playing various roles, modified over time, and it was never actually understood to which military units and according to which crietria they were given. They were encountered with equestrian units, veterans, parts of legions (vexillatio), praetorian and scout cohorts and some other units (RE VIII.A.2: 2451). A vexillum is a square flag hung across a piece of wood on top of a spear. Sometimes, there was an eagle, Victoria or some other figure on top (RE VIII.A.2: 2451-2452). The legionary eagle represented the insignia of every legion (numen legionis) 
although the appearance of specific military insignia is known, the question of their allotment to certain military formations has not yet been completely answered (Rossi 1965: 41-81; Helgeland 1978: 1473-1480; Борић-Брешковић 1986: 132133, ref. 50-56).

Ever since the 1st century $\mathrm{BC}$, as reverse motives, different military insignia appeared on Republican coins. On early Imperial coins, they became quite usual, both on imperial and provincial mintings. They appeared independently, sometimes without an inscription that would indicate whether the series was dedicated to a specific legion or any other military formation, but also with inscriptions containing the names of specific legions. On the other hand, they also appeared with numerous motives as accompanying attributes, such as: Concordia/Fides militum/ exercituum, Princeps iuventutis, Matri castrorum, Virtus, Profectio, Adlocutio, etc. A special place is taken by reverse motives and insignia with an accompanying legend SIGNIS RECEPTIS, indicating the return of previously seized military insignia. As already mentioned, the loss of military insignia represented the biggest disgrace for a legion. Such tragic events were noted several times in the history of Roman warfare. In certain cases, the seized military insignia were later retrieved, while some remained forever lost or their destiny remained unknown.

During the $1^{\text {st }}$ century $\mathrm{BC}$, the Romans were severely defeated three times by the Parthians, their legionary eagles seized and many soldiers captured. The first time was in $53 \mathrm{BC}$, the defeat and death of Crasus by Carrhae, after that in 40 $\mathrm{BC}$, there was the defeat of the Syrian governor Decidius Saxa in Cilicia and finally, in 36 BC, the defeat of Mark Antony, during his retreat from

and, as such, it was respected in a special sanctuary within the military camp. It consisted of a spear with a silver or gold-plated eagle on top, holding a lightning bolt in its talons. They were introduced at the end of the $2^{\text {nd }}$ century $\mathrm{BC}$, during Marius' military reform, when each legion was given a number and an eagle, as a symbol of the supreme Roman divinity, Jupiter (Helgeland 1978, 1473).
Media. ${ }^{3}$ Although it was never specifically stated, it is presumed that, in $19 \mathrm{BC}$, a legionary eagle was lost by one of the legions during in the final stages of the war against the Cantabri and Asturians. ${ }^{4}$ Following this incident, there was a huge shock, which left a strong impression in Rome, caused by the loss of three legions and their insignia ( $L e$ gio XVII, Legio XVIII and Legio XIX), in $9 \mathrm{AD}$, in Teutoburg Forest (Dio Cass. LVI. 21-22; Suet. Aug. 23). In $66 \mathrm{AD}$, during the First Judean war, a legionary eagle was lost by the Legio XII Fulminata and its destiny remains unknown. ${ }^{5}$ In $70 \mathrm{AD}$, during the Revolt of the Batavi, under Civilis, the Legio XV Primigenia was completely destroyed, while the Legio V Aleudae suffered severe losses. On this occasion, some of the insignia were lost, although it can not be said with any certainty to which legions they belonged (Tacit, Historije, IV, 16, 18). ${ }^{6}$ In 86 AD, during Domitian's Dacian wars, the Legio V Aleudae was finally destroyed and on that occasion, it lost its legionary eagle, whose destiny remains unknown. ${ }^{7}$ Also uncertain

3 The battle of Carrhae, in which some 20.000 soldiers died and an additional 10.000 captured, represents one of the greatest defeats in Roman history (Plut. Life of Crassus, 31.7; CAH IX, 611-612). For the defeat in Cilicia, $c f$. Dio Cass. XL.25; CAH IX, 47. When it comes to losses, an approximate equivalent to Crasus "defeat was the one of Mark Antony, when about 25.000 soldiers were lost (CAH $X, 33-34$, ref. 159)

4 In 19 BC, during the final stages of this long and difficult war, the command was taken over by Agrippa. He finally succeeded to crush the rebellion, although with great losses. One of the legions (presumably the Legio I Germanica) lost its honorary name Augusta (Dio. Cass. LIV.11.5) and it is, therefore, suspected that it lost its eagle or signum.

5 About 400 legionaries of the legion XII Fulminata died defending their military insignia. As a result of this heroic act, the legion was not punished for the loss of the insignia, but it was restored (Helgeland 1978, 1475, ref. 14).

6 Legio XV Primigenia was not restored, unlike the Legio $V$ Aleudae. However, during Domitians' Dacian wars, it was completely destroyed and it was not restored thereafter.

7 Suetonius states that Domitian lost two legions in Dacia: the first one after the defeat of the consul Opius Sabinus and the second one after the defeat of Cornelius Fuscus, the praefectus of the praetorian cohorts (Suet. Domit. 6). According to historians' opinions, during the second defeat of Cornelius Fuscus, the Legio V Aleudae was destroyed, never to be restored (Salmon 1990, 248; Jones 

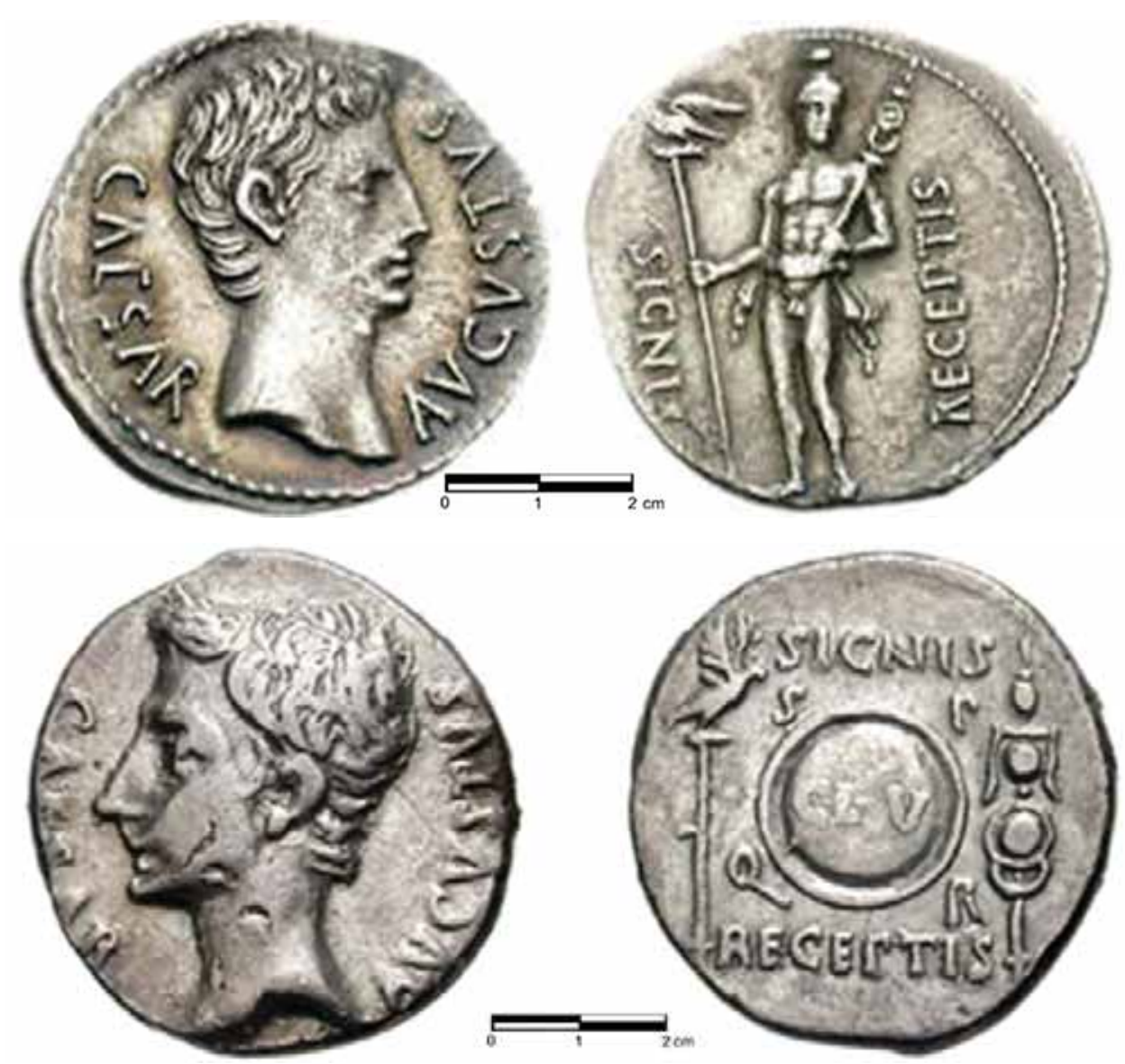

Fig. 1-2 Avgust Oktavijan (preuzeto: http://www.ancientcoins.ca/RIC/index.htm);

is the destiny of the Legio XXII Deiotariana and its legionary eagle. ${ }^{8}$ However, ever since Momsen, the greatest scientific discussion revolves around the Legio IX Hispania, whose disappearance has been left without any satisfactory explanation. ${ }^{9}$

1992, 141).

8 In $119 \mathrm{AD}$, the legion was attested for the last time (or maybe in 123), as it was still stationed in Alexandria. The next known legion list is from the time of Marc Aurel, but the Legio XXII Deiotariana does not exist in it any more. There is a presumption that it was destroyed between 132135, during the second Judean War (Keppie 2000, 223224, 225-232). Nevertheless, this scenario is considered uncertain and it is generally not accepted as a fact (Menahem 2003, 118).

9 For a long time, there was an opinion that, soon after 108 , the legion was destroyed in Britain. However, the latest evidence discovered in Holland shows that in 108, the legion was still stationed on the lower Rhine, most likely between 121 and 130 (CAH XI 2000, 497). Based on this, two new theories evolved: the legion was either destroyed during the second Judean War (132-135) or during the Parthian War, during the reign of Marc Aurel (161-166) (Keppie 2000, 173-181 with bibliography).
Only three times during the Principate do reverse motives of signis receptis appear; on coins of Augustus Octavian, Caligula and Vespasian. Between the years 20 and $18 \mathrm{BC}$, the greatest number of different types appear on Augustus mintings:

1. Rv. SIGNIS (above) RECEPTIS (below), Mars, standing and holding an aquila in right hand, wearing a standard over left shoulder (RIC I: 44, no. 41; 46, no. 58; 47, nos. 80-84) (Fig. 1).

2. Rv. SIGNIS RECEPTIS, Aquila (on left) and standard (on right) flanking S P Q R arranged around shield inscribed CL V. (RIC I: 47, nos. 8587) (Fig. 2).

3. Rv. CAESAR AVGVSTVS SIGN RECE, Kneeling Parthian, presenting standard with his right hand (RIC I: 62, no. 287) (Fig. 3).

4. Rv. CIVIB ET SIGN MILIT A PART RECVP, Facing quadriga on central part of trium- 


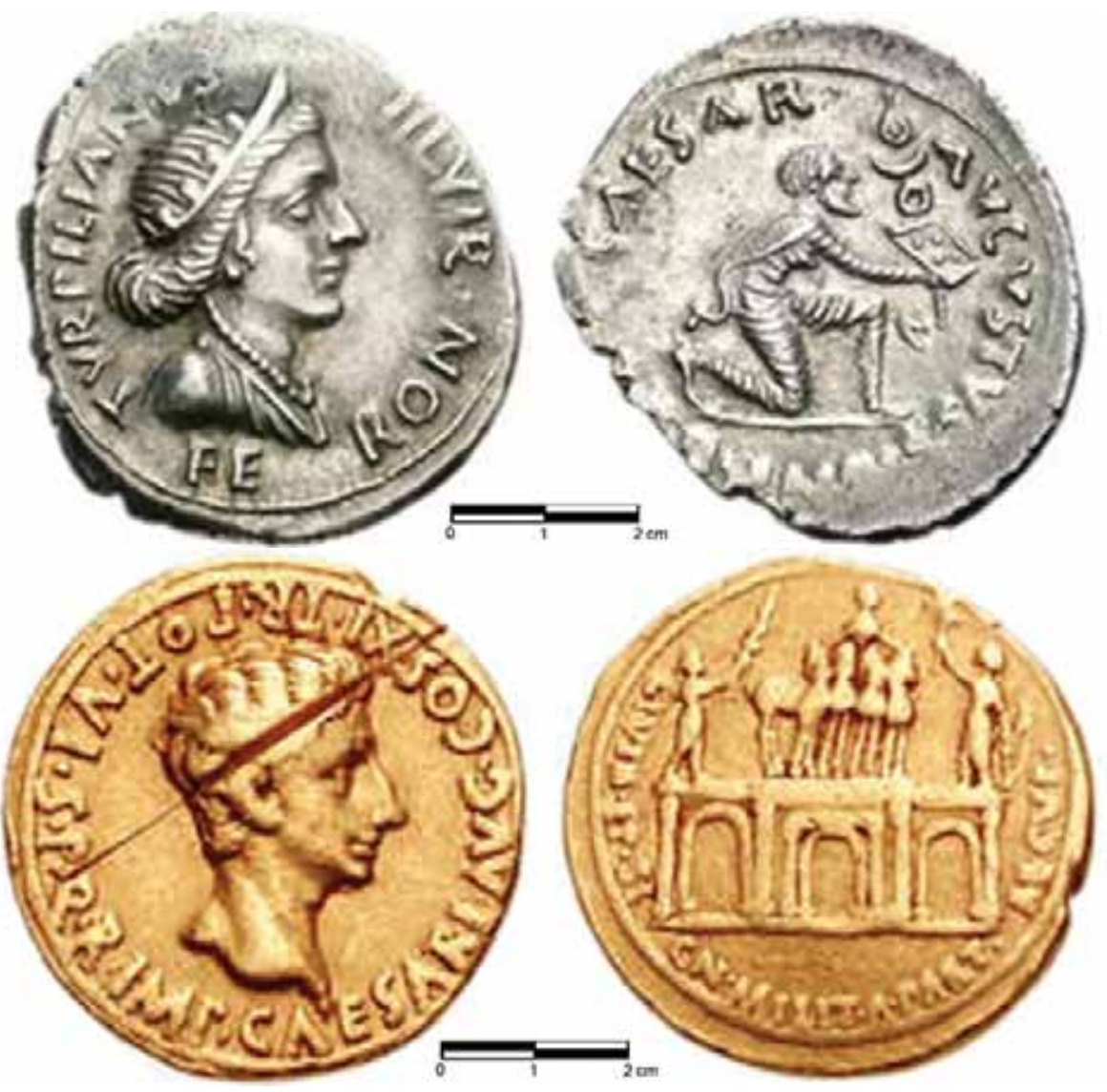

Fig. 3-4 Avgust Oktavijan (preuzeto: http://www.ancientcoins.ca/RIC/index.htm)

phal arch: figures on left and right hold, respectively, standard, Aquila and bow. (RIC I: 50, nos. 131-137) (Fig. 4).

5. Rv. S P R SIGNIS RECEPTIS, legend in three lines in the opening of the triumphal arch; above the opening, there is the inscription IMP IX TR PO IV or V; on top of the arch there is a triumphal quadriga; to the left and right, on each wall there is an aquila (RIC I: 82 , nos. 508-510) (Fig. 5).

6. Rv. SIGNIS RECEPTIS or SIGNIS PARTHICIS RECEPTIS, Capricorn on right (RIC I.. 83, nos. 521-522) (Fig. 6).

7. Rv. SIGNIS PARTHIC RECEPT or SIGNIS PARTHICIS RECEPTIS, inscription in three lines (RIC I: 83, nos. 523-526) (Fig. 7).

Such aurei and denarii commemorate the retrieval of the standards previously captured by the Parthians, as well as of the captured soldiers, which all occurred as a result of Augustus' great diplomatic activity. On this occasion, he was acclaimed imperator for the ninth time, while this diplomatic victory was celebrated in Rome as a victory on the battle-field, with a triumph and a triumphal arch. The standards that were brought to Rome were dedicated to Mars Ultor and were temporarily placed in the small temple on the Capitoline Hill, while in the year $2 \mathrm{BC}$, they were transferred to the glorious temple in Augustus' forum, dedicated to Mars Ultor (CAH X: 263). In connection to the dedication of the retrieved standards to this deity, as a reverse motive, there is a round temple with Mars standing in it, holding an aquila and a trophy, but with legend MAR VLT (RIC I: 46, no. 68) (Fig. 8).

Reverse motives clearly reflect different aspects of this event: a subordinated Parthian handing over a standard; Mars Ultor, to whom the stan- 


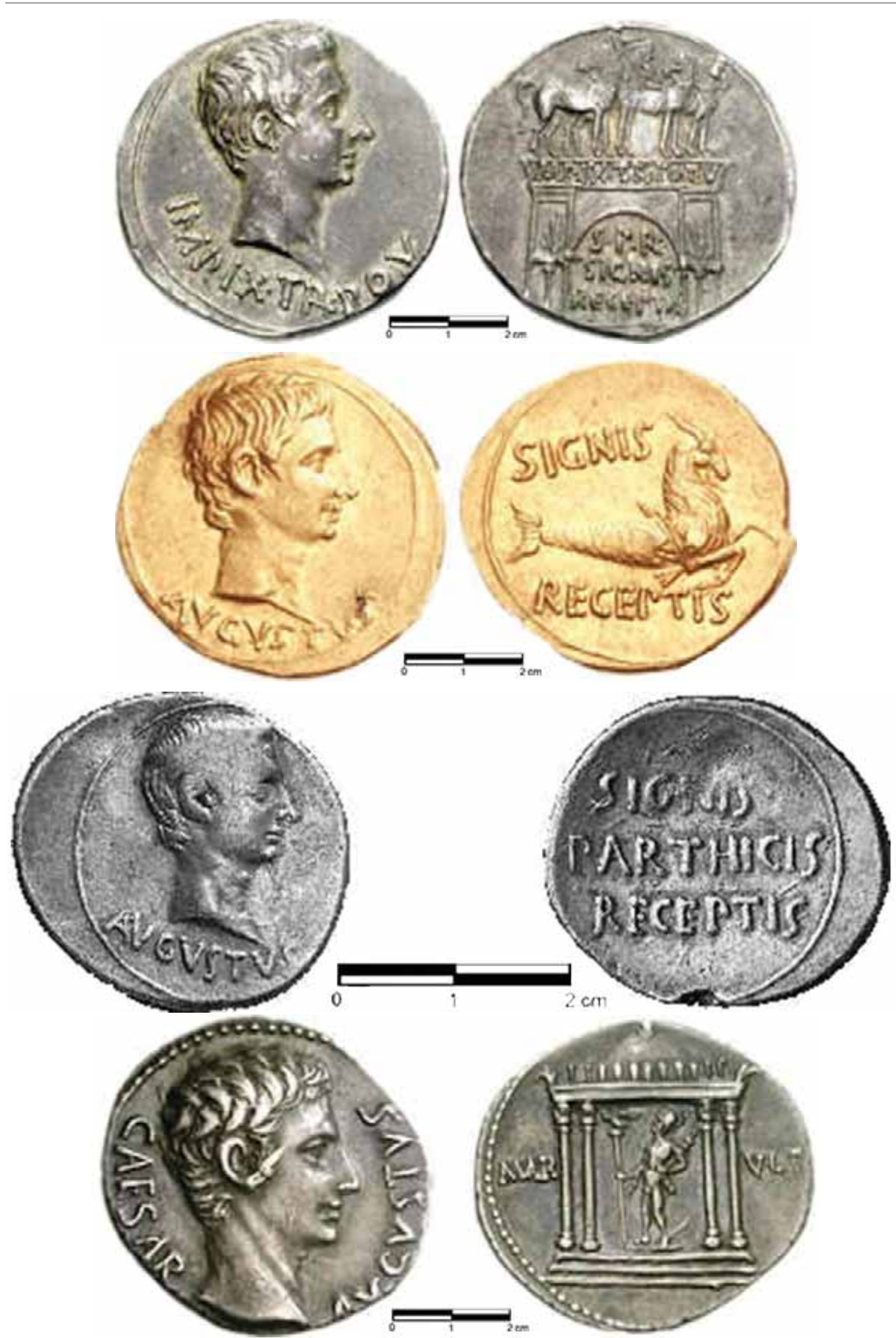

Fig. 5-8 Avgust Oktavijan (preuzeto: http://www.ancientcoins.ca/RIC/index.htm) 


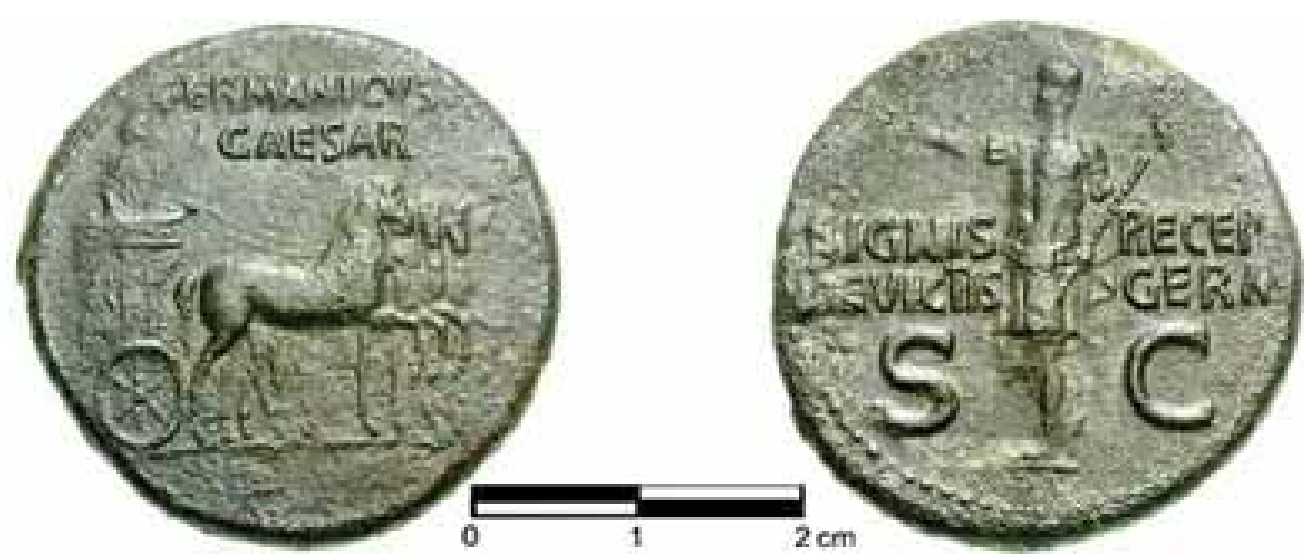

S1.9 Kaligula (preuzeto: http://www.ancientcoins.ca/RIC/index.htm);

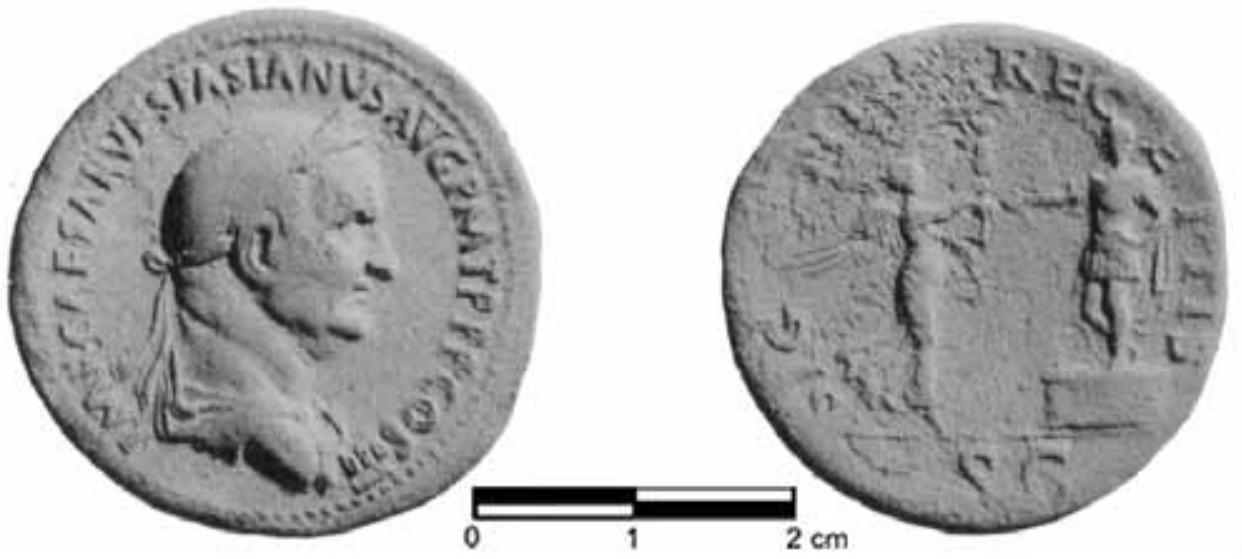

S1. 10 Vespazijan (preuzeto: BMC II, Pl. 35.6)

dards were dedicated, with the temple they were kept in; an image of the triumphal arch, built to honour this event, with the image of an aquila; Aries, the birth sign of Augustus, was considered a good omen; an image reflecting Augustus' virtues, owing to which he managed to retrieve the standards - the motive of the shield of virtues, given to him by the Senate. ${ }^{10}$

After one of the heaviest Roman defeats in Teutoburg Forest, it took over twenty years to retrieve the legionary eagles of two legions. This was during Germanicus' campaigns against the Germans. The eagle of the Legio XIX was retrieved in $15 \mathrm{AD}$ and another one the year after

10 In $27 \mathrm{BC}$, the shield of virtues (clipeus virtutis) was given to Augustus by the Senate for "virtutis clementiaeque iustitiae et pietatis causa", virtues that represent a sum of qualities that must be owned by a good princeps. This is a motive that often appears on Augustus' mintings (RIC Ia, 46).
(Tacitus, Annales, I.60; II: 25). The third eagle was only retrieved in $41 \mathrm{AD}$, during Claudius' reign (Cass. Dio, LX.8.7). Caligula minted commemorative mintings to honour Germanicus and his victories over the Germans:

8. Av. GERMANICVS CAESAR, Germanicus, bare-headed, with a cloak, standing in an ornamented slow quadriga, on right; in left hand he holds an eagle-tipped sceptre.

Rv. SIGNIS RECEPT DEVICTIS GERM S C, Germanicus in military dress, standing left, raised right arm and holding an aquila in his left (RIC I: 112, no. 57) (Fig. 9).

In $17 \mathrm{AD}$, Germanicus celebrated a triumph for his victories in Germany and retrieving the eagles lost under Varo. On this occasion, a triumphal arch was built close to the ancient Temple of Saturn (Tacitus, Annales, II.41; Cass. Dio, LVII.18.1). On coins, Germanicus is shown as a 
triumphator, on the obverse in a quadriga with a sceptre, on the reverse in a military suit, holding an Aquila that he managed to retrieve to Rome. The gesture of the raised right arm, to shoulder height or higher, was connected only to the emperor or members of his closest family, expressing untouchable power (Brilliant 1963: 68-69).

Only once more during the Principate, in 71 $\mathrm{AD}$, during Vespasian's reign, does the inscription SIGNIS RECEPTIS appear on coins:

9. Rv. SIGNIS RECEPTIS S C, Victoria flying right and offering aquila to Vespasian, standing to the left, on a platform (RIC II : 71, no. 461) (Fig. $10)$.

It is not completely clear which quila is represented. One of the possibilities is that it represents the aquila of the Legio XV Primigenia, lost during Civilis' uprising in Gaul, which ended in 70 AD (RIC II, 8; Gambash, Gitler and Cotton 2013: 100). The other, less plausible, possibility could be connected to the Fall of Jerusalem, in $71 \mathrm{AD}$ and the possible retrieval of the aquila of the Legio XII Fulminata (Bianco 1968: 208-209).

The official religion of the Roman army was conceived in such a way as to secure the soldiers' satisfactory lives, actually to enrich the meaning of the soldiers' lives. It represented a system of cultic rituals regulated for all of the military units, no matter in which part of the Empire they were stationed. Besides this official military religion, there were religious rituals brought by various soldiers and respected for private reasons. A special feature of the Roman army was the huge symbolic meaning of the insignia, which played an important role both in soldiers' every-day and cultic lives. Our knowledge about the religious meaning of the insignia of specific military units is limited, although the cult of the legionary eagle is very well documented. The aquila was paid divine respect, mostly because it was connected to the supreme deity Jupiter. The day when a newly established legion was given an aquila was celebrated as diem natale aquilae. It was kept in a special sanctuary within military camps, along with other insignia. It was regularly honoured during different rituals. The loss of an aquila during battle would represent the ritual death of a legion, which would be dismissed and never restored with the same number and name (Baumgarten 2002: 8788). Romans rarely lost their aquilae, but in cases when it occurred, they tried for decades to retrieve them. Some of these events were immortalised with depictions on coins, remaining as an eternal testimony to the great dedication and to the losses suffered in order to retrieve the aquila.

\section{BIBLIOGPRAHY}

\section{Baumgarten, A. I. 2002}

Sacrifice in Religious Experience, Köln: Brill.

\section{Bianco, E.1968}

Indirizzi programmatici e propagandistici nella monetazione di Vespasiano, Rivista italiana di numismatica e Scienze Affini (Milano) LXX,145229.

\section{BMC II - Mattingly, H. 1930}

Coins of The Roman Empire in the British Museum, Vol. II, Vespasian to Domitian, London: British Museum Trustees.

\section{Борић-Брешковић, Б. 1986}

Реверсне представе на новцу колоније Виминацијум, Зборник Народног музеја XII-1: 123-198.

\section{Brilliant, R. 1963}

Gesture and Rank in Roman Art, New Haven Connecticut: Academy of Art and Sciences.

CAH IX = Cook, S. A., Adcock, F. E. and Charlesworth, M. P. (eds.) 1932

The Cambridge Ancient History, Vol. IX, The Roman Republic, 133 - 44 B.C., Cambridge: Cambridge University Press. 
CAH X - Bowman, A. K., Champlin, E. and Mass.-London: Harvard University Press.

Lintott, A. (eds.) 2006

The Cambridge Ancient History, Vol. XI, The Augustan Empire, 43 B.C.-A.D. 69 (2nd ed.), Cambridge: Cambridge University Press.

RE II - Paulys Realencyclopädie der classischen Altertumswissenschaft Bd. II 1896

Apollon bis Artemis, Stuttgart : J. B. Metzler.

CAH XI - Bowman, A. K., Garnsey, P. and Rathbone, D. (eds.) 2000

RE II.A.2 - Paulys Realencyclopädie der classischen Altertumswissenschaft, Bd. II.A.2 1923

The Cambridge Ancient History, Vol. XI, The High Empire, A.D. 70-192 (2nd ed.), Cambridge: Cambridge University Press.

DioCass. - Cassius, Dio. 1924

Selinuntiabis Sila, Stuttgart: J. B. Metzler.

RE VIII.A.2 - Paulys Realencyclopädie der classischen Altertumswissenschaft, Bd. VIII.A.2 1958

Roman History, Trans. by E. Cary, Loeb Classical Library. Cambridge Mass., London: Harvard University Press.

P. Vergilius Marobis Vindeleia, Stuttgart: J. B. Metzler.

\section{RIC I - Sutherland C. H. V. 1984}

Gambash, G., Gitler, H. and Cotton H. M. 2013 The Roman Imperial Coinage, Vol. I, From 39 BC IUDAEA RECEPTA, Israel Numismatic Research (Tel Aviv) 8/2013, 89-104.

\section{Helgeland, J. 1978}

to $A D$ 69, London: Spink\&SonLtd.

RIC Ia - Mattingly, H. and Sydenham, E. A. 1968

Roman Army Religion, in: Aufstieg und Niedergang der Römischen WeltII.16.2, Berlin-New York: de Gruyter, 1470-1505.

Jones, B. W. 1992

The Emperor Domitian, London: Routledge.

Keppie, L. 2000

The Roman Imperial Coinage, Vol. I, Augustus to Vitellius, London: Spink \& Son Ltd.

RIC II - Mattingly H.andSydenham E. A. 1962 The Roman Imperial Coinage, Vol. II, Vespasianto Hadrian, London: Spink \& Son Ltd.

Rossi, L. 1965

Legions and veterans, Roman army papers1971-2000, Stuttgart: Steiner.

Menahem, M. 2003

The Geographical Scope of the Bar Kokhba Revolt, in: The Bar Kokhba War Reconsidered: New Perspectives on the Second Jewish Revolt Against Rome, (ed. P.Schäfer) Tübingen: Mohr Siebeck: 107-132.

\section{Plut. LifeofCrassus - Plutarch 1916}

Lives, Vol. III, Periclesand Fabius Maximus. Nicias and Crassus, Loeb Classical Library no. 65, Transleted by Bernadotte Perrin, Cambridge

Le insegne militari nella monetazione imperiale romana da Augusto a Commodo, Rivista italiana di numismatica e Scienze Affini (Milano) LXVII: 41-81.

\section{Salmon, E. T. 1990}

A History of the Roman World from 30 B.C. to A.D. 138 (6th ed.), London: Routledge.

\section{Stoll, 0.2007}

The Religion softhe Armies, in: A Companion to the Roman Army, P. Erdkamp (ed.), Oxford: Blackwell Publishing Ltd. 
Suet. - Svetoni, C. T. 1978

Dvanaest rimskih careva, (pr.) S. Hosu, Rijeka: Naprijed.

Tacit Anali - Tacitus, P. C. 1970

Анали, ( пр.) Љ. Црепајац, Београд: Српска књижевна задруга.

Tacit Historije - Tacitus P. C. 1987

Historije, (pr.) J. Miklić, Zagreb: VPA.

REZIME

SIGNIS RECEPTIS KAO REVERSNI MOTIV NA RIMSKOM CARSKOM NOVCU

KLJUČNE REČI: RIMSKI CARSKI NOVAC, REVERSNA PREDSTAVA, SIGNA MILITARIA, SIGNIS RECEPTIS.

Oficijelna religija rimske vojske bila je koncipirana tako da obezbedi zadovoljavajući život vojnika, odnosno da obogati smisao vojničkog života. Predstavljala je sistem kultnih obreda kojisu bili propisani za sve vojne jedinice, bilo gde da su bile stacionirane u Carstvu. Pored ove oficijelne vojne religije, izdvajaju se religiozni obredi koje su vojnici doneli sa sobom i koje su poštovali iz privatnih razloga. Posebna karakteristika rimske vojske bilo je veliko simbolično značenje insignija, koje su imale ulogu kako u svakodnevnom, tako i u kultnom životu vojnika. Naše znanje o religijskom značaju insignija pojedinih odreda vojske je ograničeno, ali kult legionarskog orla je veoma dobro dokumentovan. Akvili su ukazivane božanske počasti, samim tim što je bila povezana sa vrhovnim božanstvom Jupiterom. Dan kada je novoustanovljena legija dobila akvilu proslavljan je kao diem natale aquilae. Sa drugim insignijama čuvana je u okviru logora u posebnom svetilištu, gde joj redovno ukazivane počasti u sklopu različitih ritualnih radnji. Gubitak akvile tokom bitke značio je ritualnu smrt legije, koja bi bila raspuštena i nikada nije ponovo formirana legija sa istim brojem i imenom.

Ovakvi tragični događaji zabeleženi su nekoliko puta u istoriji rimskog ratovanja, u izvesnim slučajevima zaplenjene vojne insignije su kasnije povraćene, dok su neke ostale zauvek izgubljene ili je njihova sudbina ostala nepoznata.

Neki od tih događaja zabeleženi su predstavama na novcu sa legendom SIGNIS RECEPTIS. Pojavljuju se u kovanjima Avgusta, Kaligule i Vespazijana. Najveći broj različitih tipova reversnih predstava iskovan je između 20. i 18. g. s. e. povodom povratka ranije zaplenjenih insignija od strane Parćana. Sjajnom diplomatskom aktivnošću je Avgust Oktavijan uspeo da mirnim putem povrati rimske svetinje i preživele zarobljenike. U kovanju Kaligule se pojavljuje komemorativni novac u sećanje na njegovog oca Germanika i povratka legionarskih orlova izgubljenih u Teutoburškoj šumi. Motiv signis receptis pojavljuje se smo još u kovanju Vespazijana iz 71. g.n.e. s tim što ostaje nejasno koja akvila je u pitanju (Legio XV Primigeniaili Legio XII Fulminata).

Rimljani su retko gubili akvile, a i u tim slučajevima su decenijama pokušavali da ih povrate. Neki od tih događaja obeleženi su i predstavama na novcu i ostali zauvek kao svedočanstva velike požrtvovanosti i gubitaka uloženih u njihov povratak. 